Kong. Res. J. 2(2) : 110-113, 2015

ISSN 2349-2694

Kongunadu Arts and Science College, Coimbatore.

\title{
ANTIMICROBIAL EFFICACY OF THE FOLKLORE MEDICINAL PLANT, ACACIA CAESIA (L.) WILD
}

\author{
Thambiraj, J' ${ }^{1}$ and S. Paulsamy ${ }^{2 *}$ \\ ${ }^{1} \mathrm{PG}$ and Research Department of Botany, The Madura College (Autonomous), Madurai - 625011. \\ ${ }^{2} \mathrm{PG}$ and Research Department of Botany, Kongunadu Arts and Science College, Coimbatore - 641029. \\ *E.mail: paulsami@yahoo.com
}

\begin{abstract}
Leaf extracts of the folklore plant species, Acacia caesia L. by using three alcoholic solvents viz; petroleum ether, ethyl acetate and methanol were tested against ten human pathogenic bacteria viz., Pseudomonas aeruginosa, P. stutzeri, Escherichia coli, Micrococcus sp., Lactobacillus sp., Servatia sp., Moraxetta sp., Bacillus subtilis, B. thuriengensis, and Klebsiella pneumoniae and ten human pathogenic fungi viz., Aspergillus niger, A. flavus, A.baumannii, Fusarium oxysporum, F. solani, Mucor rouxii, Alternaria alternata, Candida albicans, Cladosporium sp. and Rhizopus sp. for assessing the antimicrobial properties by adapting disc diffusion method. The results of the study revealed that all extracts showed varied degree of antimicrobial activity against the tested pathogens. However, the ethyl acetate extracts exhibited higher inhibition zone (15.73 mm) against the bacterium, Bacillus subtilis and the fungus, Mucor rouxii (20.67 mm). These results support the therapeutic importance of the species, Acacia caesia in curing infectious diseases and encourage the extensive use of this species in health care practices.
\end{abstract}

Keywords: Medicinal plant, Acacia caesia, Antimicrobial activity, Microorganisms.

\section{INTRODUCTION}

Located in a tropical belt, India is endowed with a rich wealth of fauna and flora with inumerous medicinal plants. These plants have made a good contribution to the development of ancient Indian Materia Medica. One of the earliest treatises on Indian medicine, the Charaka Samhita (1000 B.C), records the use of over 340 drugs of vegetable origin (Pullaih, 2006). Most of these continue to be gathered from wild plants to meet the demand of the medical profession. India, in particular, has a big scope for the development of the pharmaceutical and phytochemical industry. Traditionally different parts of several medicinal plants or their extracts are used in treatment of various diseases in India (Balakrishnan et al., 2006). Among them, many species of Acacia are found to have diverse photochemical compounds of medicinal properties (Lee et al., 2000; Readel et al., 2001; Seo et al., 2002; Sathishkumar et al., 2009). Acacia caesia L. belongs to the family, Mimosaceae is one such folklore plant used in traditional system of medicine in Coimbatore district of Tamil Nadu, India. It is an armed woody shrub occurring throughout the tropical and sub-tropical regions of India (Krishnamurthy, 1993). This plant species has been used as a folk remedy for the treatment of skin diseases, asthma, bronchitis, scabies, cold, menstrual disorders and antiseptic also. The leaves of this plant are used as vegetable and the powdered bark and pod are used as substitute for soap and their decoctions as lice killer (Thammanna, 1990). Woody branches of this species are used as tooth brushes by tribal folk and the shrub is used as fuel wood. However, no published works are available for the antimicrobial property of leaf part of this plant. Hence in the present study, an attempt has been made to focus the plant in this angle and hence to assess its therapeutic potency.

\section{MATERIALS AND METHODS}

\subsection{Plant material}

Fresh leaf parts were collected from the population of $A$. caesia present in the Maruthamalai Hills of Coimbatore District and washed under running tap water, air dried and then homogenized to fine powder and stored in air tight bottles.

\subsection{Preparation of extracts}

$250 \mathrm{~g}$ air-dried leaf powder was subjected to $250 \mathrm{ml}$ of methanol in soxhlet extraction for 8 hours $\left(50-85^{\circ} \mathrm{C}\right)$. The extracts were concentrated to dryness in a flask evaporator under reduced pressure and controlled temperature $\left(50-60^{\circ} \mathrm{C}\right)$ to yield crude residue, which was then stored in refrigerator. To obtain petroleum ether and ethyl acetate extracts, the same method as used to obtain methanol extract was adopted.

\subsection{Media used}


Freshly prepared nutrient agar medium and PDA medium were used for the culture of bacteria and fungi respectively.

\subsection{Microorganisms}

In vitro antimicrobial activity was examined for the chemical extracts of leaf part of the study plant, against ten bacterial species which include the gram positive strains viz., Micrococcus sp., Lactobacillus sp., Bacillus subtilis, B. thuriengensis and gram negative strains viz., Pseudomonas aeruginosa, P. stutzeri, Escherichia coli, Klebsiella pneumoniae, Servatia sp. and Moraxetta sp. and fungal species viz., Aspergillus niger, A. flavus, A. baumannii, Fusarium oxysporum, F. solani, Mucor rouxii, Alternaria alternata, Candida albicans, Cladosporium sp. and Rhizopus sp. All these microorganisms were obtained from the Department of Microbiology, Tamil Nadu Agricultural University, Coimbatore. All the microorganisms were maintained at $4^{\circ} \mathrm{C}$ on nutrient agar slants (for bacteria) and PDA slants (for fungi) until furtheruse.

\subsection{Antimicrobial assay}

The alcoholic extracts were tested for their effect against the growth of pathogenic bacteria and fungi by disc diffusion method (Bauer et al., 1966). Both the organisms, bacteria and fungi tested were inoculated into nutrient agar and PDA media respectively. After an incubation period of $24 \mathrm{hrs}$ at a temperature of $35^{\circ} \mathrm{C}$, three or four colonies isolated from these media were inoculated into $4 \mathrm{ml}$ of nutrient broth and incubated for $2 \mathrm{hrs}$ at $35^{\circ} \mathrm{C}$. The cultures were adjusted with sterile saline solution to obtain turbidity. Petri dishes containing MullerHinton agar medium and PDA medium were streaked with these microbial suspensions of bacteria and fungi respectively. Disks of $6 \mathrm{~mm}$ diameter were impregnated with the extracts of petroleum ether, methanol and ethyl acetate separately. Tetracycline is used as positive control. After equilibrium at $4^{\circ} \mathrm{C}$, the plates were incubated overnight at $37^{\circ} \mathrm{C}$ and the diameter of any resulting zones of inhibition was measured. Each experiment was repeated at least three times.

\section{RESULTS AND DISCUSSION}

The antibacterial activity of the all the alcoholic leaf extracts of the study species, Acacia caesia generally showed inhibitory activity against the growth of Bacillus thuringiensis and Lactobacillus sp. However, towards Pseudomonas aeruginosa, P. stutzeri, Escherichia coli, Micrococcus sp., Serratia sp., Moraxetta sp., Bacillus subtilis and Klebsiella pneumoniae, all these extracts showed activity with less pronounced manner (Table 1). It is explained that the different phytochemicals like steroids, cardiac glycosides, anthraquinone, flavonoids and phenolics extracted by different solvents may be responsible for their antibacterial effects (Tambekar and Khante, 2010). Further, the ethyl acetate extract has determined to have highest inhibitory activity (15.73 mm diameter inhibitory zone) against the bacterium, Bacillus subtilis (gram positive) and (14.83 $\mathrm{mm}$ diameter inhibitory zone) against the bacterium, $B$. thuringiensis followed by the methanol extract against the bacterium, Escherichia coli, (gram negative) (12.43 $\mathrm{mm}$ diameter inhibitory zone). It indicates the presence of effective active principle compounds in the ethyl acetate and methanol extracts of leaf part of $A$. caesia to suppress both gram negative and gram positive bacteria. It has been observed further that the ethyl acetate extracts showed significantly higher inhibitory activity against the colonial growth of Bacillus subtilis and $B$. thuringiensis than that of the commercially available antibiotic, tetracycline. This fact shows the higher therapeutic potential of ethyl acetate extract of the study species. The petroleum ether extract has comparatively less activity against most of the tested pathogens. It may be attributed to the presence of respective active compounds with insufficient quantities in this crude extract (Taylor et al., 2001).

The antifungal activity of various alcoholic leaf extracts of the study species, Acacia caesia against the ten studied fungal species is given in Table 2 . The results of the study report that the ethyl acetate extract has the highest inhibitory activity (20.67 $\mathrm{mm}$ diameter inhibitory zone) against the fungus, Mucor rouxii. The petroleum ether and methanol extracts were also found to be better with respect to inhibitory function against the two fungal species, Mucor rouxii and Rhizopus sp. (17.73 and $16.75 \mathrm{~mm}$ diameter inhibitory zone respectively).

This fact indicats the existence of strong antifungal activity of leaf part of the study species, $A$. caesia and hence its effective healing property against the infectious diseases. The variation in antifungal activity across the extracts studied may be due to the polarity of the solvents used. Significantly higher inhibitory activity of ethyl acetate extract is nearly to the commercially available antibiotic tetracycline against the fungus, Mucor rouxii observed shows the superior healingness of leaf part of $A$. caesia. Proper isolation and purification of active compounds by using ethyl acetate solvent would ensure the therapeutic value of this folklore medicinal plant when it will be used commercially. 
Table 1. Antibacterial activity of certain alcoholic leaf extracts of the species, Acacia caesia.

\begin{tabular}{|c|c|c|c|c|c|c|c|c|c|c|}
\hline \multirow{3}{*}{$\begin{array}{c}\text { Plant } \\
\text { extract }\end{array}$} & \multicolumn{10}{|c|}{ Diameter of zone inhibition (mm) } \\
\hline & \multicolumn{4}{|c|}{ Gram positive bacteria } & \multicolumn{6}{|c|}{ Gram negative bacteria } \\
\hline & BS & BT & $\begin{array}{l}\text { MC } \\
\text { sp. }\end{array}$ & L sp. & KP & EC & PS & PA & S sp. & M sp \\
\hline Standard* & $\begin{array}{c}8.53 \\
\pm \\
0.56\end{array}$ & $\begin{array}{c}8.33 \\
\pm 0.35\end{array}$ & $\begin{array}{c}22.43 \\
\pm \\
0.40\end{array}$ & $\begin{array}{r}24.03 \\
\pm 0.45\end{array}$ & $\begin{array}{l}15.43 \\
\pm 0.44\end{array}$ & $\begin{array}{c}30.43 \\
\pm \\
0.40\end{array}$ & $\begin{array}{c}12.73 \\
\pm \\
0.46\end{array}$ & $\begin{array}{c}26.61 \\
\pm \\
0.54\end{array}$ & $\begin{array}{l}14.93 \\
\pm 0.31\end{array}$ & $\begin{array}{r}8.87 \\
\pm 0.42\end{array}$ \\
\hline $\begin{array}{c}\text { Petroleum } \\
\text { ether }\end{array}$ & - & $\begin{array}{r}12.76 \\
\pm 0.62\end{array}$ & - & $\begin{array}{c}8.07 \\
\pm 0.55\end{array}$ & - & - & - & - & - & - \\
\hline $\begin{array}{c}\text { Ethyl } \\
\text { acetate }\end{array}$ & $\begin{array}{c}15.73 \\
\pm \\
0.70\end{array}$ & $\begin{array}{r}14.83 \\
\pm 0.80\end{array}$ & - & $\begin{array}{c}8.03 \\
\pm 0.44\end{array}$ & $\begin{array}{r}8.03 \\
\pm 0.15\end{array}$ & $\begin{array}{l}12.17 \\
\pm 0.35\end{array}$ & $\begin{array}{c}7.76 \\
\pm 0.70\end{array}$ & - & - & - \\
\hline Methanol & - & $\begin{array}{c}9.07 \\
\pm 0.21\end{array}$ & $\begin{array}{c}9.07 \\
\pm \\
0.46\end{array}$ & $\begin{array}{c}7.43 \\
\pm 0.59\end{array}$ & $\begin{array}{r}11.93 \\
\pm 0.40\end{array}$ & $\begin{array}{c}12.43 \\
\pm \\
0.45\end{array}$ & $\begin{array}{c}8.03 \\
\pm 0.25\end{array}$ & $\begin{array}{c}8.73 \\
\pm \\
0.67\end{array}$ & $\begin{array}{c}9.03 \\
\pm 0.25\end{array}$ & $\begin{array}{l}12.07 \\
\pm 0.40\end{array}$ \\
\hline
\end{tabular}

BS - Bacillus subtilis; BT - B. thuringiensis; MC sp. - Micrococcus sp.; L sp. - Lactobacillus sp.; KP - Klebsiella pneumoniae; EC - E. coli; PS - Pseudomonas stutzeri; PA - P. aeruginosa; S sp. - Serratia sp.; M sp. - Moraxetta sp.

* Tetracycline

Table 2. Antifungal activity of certain alcoholic leaf extracts of the species, Acacia caesia.

\begin{tabular}{|c|c|c|c|c|c|c|c|c|c|c|}
\hline \multirow{2}{*}{$\begin{array}{c}\text { Plant } \\
\text { extract }\end{array}$} & \multicolumn{10}{|c|}{ Diameter of zone inhibition (mm) } \\
\hline & AN & $\mathbf{A F}$ & $\mathbf{A B}$ & FO & FS & MR & AA & CA & C sp. & R sp. \\
\hline Standard * & $\begin{array}{c}35.23 \\
\pm \\
0.59\end{array}$ & $\begin{array}{r}38.17 \\
\pm 0.67\end{array}$ & $\begin{array}{c}33.63 \\
\pm \\
0.65\end{array}$ & $\begin{array}{l}32.73 \\
\pm 0.67\end{array}$ & $\begin{array}{l}25.73 \\
\pm 0.67\end{array}$ & $\begin{array}{l}27.63 \\
\pm 0.57\end{array}$ & $\begin{array}{c}30.67 \\
\pm \\
0.59\end{array}$ & $\begin{array}{r}16.03 \\
\pm 0.15\end{array}$ & $\begin{array}{r}13.67 \\
\pm 0.65\end{array}$ & $\begin{array}{r}36.67 \\
\pm 0.59\end{array}$ \\
\hline $\begin{array}{l}\text { Petroleum } \\
\text { ether }\end{array}$ & $\begin{array}{c}8.23 \\
\pm \\
0.49\end{array}$ & - & - & - & $\begin{array}{r}8.13 \\
\pm 0.70\end{array}$ & $\begin{array}{l}17.73 \\
\pm 0.67\end{array}$ & - & - & - & - \\
\hline $\begin{array}{l}\text { Ethyl } \\
\text { acetate }\end{array}$ & $\begin{array}{l}15.73 \\
\pm 0.67\end{array}$ & $\begin{array}{r}12.67 \\
\pm 0.61\end{array}$ & $\begin{array}{c}10.77 \\
\pm \\
0.70\end{array}$ & $\begin{array}{l}12.77 \\
\pm 0.71\end{array}$ & $\begin{array}{r}10.67 \\
\pm 0.65\end{array}$ & $\begin{array}{l}20.67 \\
\pm 0.61\end{array}$ & $\begin{array}{l}10.73 \\
\pm 0.67\end{array}$ & $\begin{array}{l}10.76 \\
\pm 0.80\end{array}$ & - & $\begin{array}{l}12.67 \\
\pm 0.59\end{array}$ \\
\hline Methanol & $\begin{array}{c}14.77 \\
\pm \\
0.70 \\
\end{array}$ & $\begin{array}{c}9.17 \\
\pm 0.38\end{array}$ & $\begin{array}{c}10.83 \\
\pm \\
0.80 \\
\end{array}$ & $\begin{array}{c}10.67 \\
\pm \\
0.65\end{array}$ & - & $\begin{array}{l}15.70 \\
\pm 0.66\end{array}$ & $\begin{array}{c}8.67 \\
\pm 0.65\end{array}$ & $\begin{array}{c}8.27 \\
\pm 0.55\end{array}$ & $\begin{array}{c}8.03 \\
\pm 0.91\end{array}$ & $\begin{array}{l}16 . .75 \\
\pm 0.73\end{array}$ \\
\hline
\end{tabular}

AN - Aspergillus niger; $\mathrm{AF}$ - A. flavus; $\mathrm{AB}$ - A. baumanii; FO - Fusarium oxysporum; FS - F. solani; MR - Mucor rouxii; $\mathrm{AA}$ - Alternaria alternate; CA - Candida albicans; C sp. - Cladosporium sp.; R sp. - Rhizopus sp.

* Tetracycline

The overall study on antimicrobial activity reports that the study species contains adequate variety of active compounds to reduce or check the growth of microbial colonies. It confirms the therapeutic value and hence the traditional usage of the leaf part of the study species, A. caesia against various ailments. Further, the alcoholic extracts of leaf part of this plant in general and ethyl acetate and methanol extracts in particular are suggested for the therapy of infectious diseases caused by pathogens and further studies are recommended to purify the active compounds for the formulation of new drugs, while go for commercialization.

\section{ACKNOWLEDGEMENT}

The authors are gratefully acknowledging the authorities of Tamil Nadu State Council for Science and Technology, Chennai for their financial assistance to carryout the work.

\section{REFERENCES}

Balakrishnan, N., V.H. Bhaskar, B. Jayakar and B. Sangeswaran, (2006). Antibacterial activity of Mimosa pudica, Aegle marmels and Sida cordiffolia. Pharmacog. Mag. 2: 198-199. 
Bauer, R.W., M.D.K. Kirby, J.C. Sherris and M. Turek, (1966). Antibiotic susceptibility testing by standard single disc diffusion method. Americ. J. Clin. Pathol. 45: 493-496.

Krishnamurthy, T. (1993). Minor Forest Products of India Oxford \& IBH Publishing Co. Ltd. New Delhi.

Lee, T.H., F. Qiu, G.R. Walle and C.H. Chou, (2000). Three new flavanol galloyglycosides from leaves of Acacia confuse. J. Nat. Prod. 10: 125.

Pullaiah, T. (2006). Encyclopedia of World Medicinal Plants. Vol. 3, Regency Publications, 20/36-G, New Delhi.

Readel, K., D. Seigier, K. Hwang, J. Keesy and S. Sellheimer, (2001). Tannins from mimosid legumes of Texas and Mexico. Econ. Bot. 55(2): 212-222.

Sathishkumar, P., S. Paulsamy, A.M. Anandakumar and P. Senthilkumar, (2009). Effect of habitat variation on the content of certain secondary metabolites of medicinal importance in the leaves of the plant, Acacia caesia Wild. J. Advan. Plant Sci. 22(11): 451-453.

Seo, Y., J. Hoch, M. Abdel-Kader, S. Malone, I. Derveld, H. Adams, M.C.M. Werkhoven, J.H. Wisse, S.W. Mamber, J.M. Dlton and D.G.I. Kingston, (2002). Bioactive saponins from Acacia tenuifolia from the Suriname Rainforest. J. Nat. Pro. 65: 170.

Tambekar, D.H. and B.S. Khante, (2010). Evaluation of antibacterial properties of ethnomedicinal herbs used by Korkus in Melghat of India against Enteric pathogens. Int. J. Pharma Bio Sci. V1(1)(http: //www.ijpbs.net).

Taylor, .JL., S.T. Rabe, L.J. McGraw, A.K. Jager and J. van Staden, (2001). Towards the Scientific Validation of traditional medicinal plants, Plant Growth Regul. 34: 23-37.

Thammanna, N.R.K. (1990). Medicinal Plants of Tirumala. $1^{\text {st }}$ ed. Department of Gardens, Tirumala Tirupahti Devasthanams, Tirupathi. 